\title{
天然ゴム配合物の加硫異方性
}

\author{
村松 凌*・竹澤 宏典・駒水 謙二
}

\section{Compression Molding Anisotropy of Natural Rubber Compounds}

\author{
Ryo MURAMATSU*, Hironori TAKEZAWA and Kenji KOMAMIZU (TOYO TIRE \& RUBBER CO., LTD., R \& D CENTER, \\ 5-7 Nishi-Chujocho, Ibaraki-shi, Osaka 567-0887, Japan)
}

By studying the physical properties of natural rubber compounds cured by compression in a test mold which has a unidirectional outer flow of excess rubber from the mold when vulcanization starts, we found that the tear strength of the test pieces where the direction of the stretching was parallel to the outer flow was lower than that of the test pieces with the direction perpendicular to it. Similar anisotropies were also observed in tensile strength, modulus, tan $\delta$, Payne's effect, etc. Some anisotropies similar to the experiments were observed in the OCTA calculation with a non-crosslinked natural rubber model. The causes of anisotropies were considered.

(Received on January 13, 2009)

(Accepted on May 18, 2009)

Key Words : Anisotropy, Natural Rubber, Compression Mold, Tear Strength, Mold Flow, OCTA, Coarse-grained Molecular Dynamics

\section{1. 緒言}

悪路用のトラック・バス用タイヤ等において，重要なゴ ム特性である引裂強さ $(T R)$ は, 天然ゴム $(\mathrm{NR})$ 配合でのば らつきが特に大きく，これらの配合を開発する際に問題と なる場合が多い．著者は，この原因の一つとして加硫時の ゴムの流れ出しに起因する異方性が問題である事を見出し た、そこで，ゴムの流れ出しを一方向に制御する事のでき る試験用金型を考案し，TRのばらつきを低減させる特許 ${ }^{1)}$ を申請した。破断特性は，ゴムの流れ方向に伸長した場合 が流れに直角方向に伸長した場合より大きいと一般的には 考える ${ }^{2)}$ が，この特許では，TRは逆に流れ出し方向が流 れに直角方向よりも小さい結果であった.

プレス加硫でのゴムの加硫異方性については幾つかの研 究が報告されている ${ }^{3-7)}$. その中で, Gurney ら ${ }^{3)}$ は上記 特許と類似の金型を用い，またHamed ら ${ }^{4)}$ は未加硫ゴム の形状と金型内での配置の工夫により，TRに及ぼす加硫 異方性について上記特許と同様な結果を報告している．但 し， 上記 2 報告 ${ }^{3,4)}$ とも引張強さ $\left(T_{\mathrm{B}}\right)$ に及ぼす加硫異方性 は認められなかった。また，安定した加硫列理の再現法や その観測法についても報告されていない.

\footnotetext{
*東洋ゴム工業株式会社 研究開発センター

（テ 567-0887 茨木市西中条町 5-7)
}

そこで，本研究では，加硫列理の観測法を含め，引裂及 び引張特性や粘弾性に及ぼす加硫異方性を検討した.

さらに，この現象について，高分子解析ソフト OCTA ${ }^{8)}$ による非架橋, 非充てんの NRの粗視化モデルを用いた解 析を試み，かかる異方性の発現要因について考察した．本 研究は第 17 回エラストマー討論会で発表した内容 ${ }^{9,10)}$ に 追試結果を加え，一部を修正したものである.

\section{2. 実}

験

\section{1 実ゴムを用いた実験}

\section{1 .1 配合ゴム}

用いたゴム配合は，A配合 ; NR/SBR1500/ISAF/プロ セス油 (83/17/40/8), B 配合; NR/SAF/プロセス油 (100/46/0), C配合; SBR1500/ISAF/プロセス油 (100/52/13) で，これらの配合ゴムに加硫促進剤や硫黄等 をそれぞれ配合し， $141{ }^{\circ} \mathrm{C} \times 45$ 分で加硫した。

\section{1 .2 使用金型}

試験用金型 (Test-Mold， 2 面取り)の下型の左側キャビ ティ部をFigure 1に示した。この金型は手前と奥の Guide-Wall 間に厚さ $15 \mathrm{~mm}$ の平板の上型(図に示していな い)を挿入し, 加圧する構造である. 左手前の壁 (Lower Wall) が中央部の壁に比べて低いため, 加圧時に $0.3 \mathrm{~mm}$ の空隙が確保され，ゴムが一方向に流れ出す設計 ${ }^{1)}$ であ 


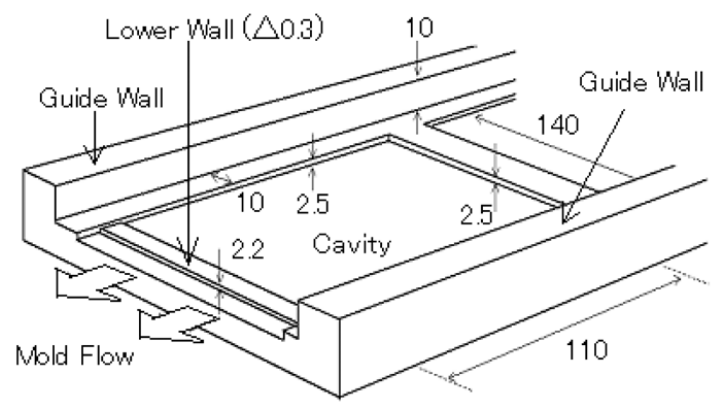

Figure 1 Sketching of Test-Mold with unidirectional flow.

る.コントロールの JIS 金型 (JIS-Mold，4 面取り) は JIS K 6299 に準じた。

\section{1 .3 引裂及び引張試験}

引裂試験はJIS K 6252 (クレセント形試験片)に従った。 但し, Table 1のデータはJIS K 6301 (A 型試験片)に拠っ た。引張試験はJIS K 6251 に準拠した。

\section{1 .4 加硫列理観測法 ${ }^{11)}$}

加硫シートをシクロヘキサンに15〜18時間浸漬後，取 り出し, 約 $5 \mathrm{~mm}$ の切込みを任意に入れ, 手で引裂いた。 引裂き後の加硫シートを乾燥し, 引裂き跡を白マーカーで マークし，引裂き前の状態に戻した状態の写真が Figure 4 である。この引裂き跡が，弱い列理パターンを示すものと 考えた。但し，この方法はNRの多い配合に限定される.

\section{1 .5 ミクロ試験}

試験用金型を用いて加硫したシートを約 $0.5 \mathrm{~mm}$ 厚みに スライスし，ミクロ引裂やミクロ引張試験，更に粘弾性の 測定に用いた。ミクロ引裂試験は， $6.5 \times 30 \times$ 約 $0.5 \mathrm{~mm}$ の試料中央部の端に $1 \mathrm{~mm}$ の切込みを付した試験片を，ま た，ミクロ引張試験はダンベル 7 号型 (JIS K 6251) 試験片 を用い，各引張速度 $50 \mathrm{~mm} /$ 分で測定した。但し，ミクロ 引裂強さは断面積当たりの応力 $\mathrm{MPa}$ で計算した。粘弾性 試験は $5 \times 20$ (チャック間) $\times$ 約 $0.5 \mathrm{~mm}$ の試験片を使用し, 室温, $50 \mathrm{~Hz}$ で計測した。

\section{1 .6 架橋密度}

架橋密度は $5 \times 25 \sim 35 \times$ 約 $0.5 \mathrm{~mm}$ の試験片をシクロ ヘキサンで膨潤させ，方向別の膨潤伸長度測定より求め た ${ }^{12)}$.

\section{1 .7 加硫ゴムシートの収縮率}

加硫後の試験シートの収縮率は, 室温でシート寸法を計 測し，金型寸法を基準にして算出した。

\section{1 .8 加硫ゴムシートの表面観測}

加硫ゴムシート表面観測は，島津製作所製SPM-9500J3 の走査型プローブ顕微鏡 (Scanning Probe Microscopy $(\mathrm{SPM}))$ を用いた。カンチレバーはNANOSENSORS製 NCHRを使用して，ダイナミックモードの位相を測定し た。

\section{2 高分子解析ソフト OCTA-Cognac ${ }^{8)}$ 解析}

2.2.1 2.2.4の粗視化分子動力学解析は, OCTA の沉用 粗視化分子動力学プログラム Cognac ${ }^{8)}$ を用いた.

\section{2 .1 非架橋, 非充てんのポリマーモデル}

ポリマーモデルは，イソプレンモノマーを粗視化(以後, 粒子と呼ぶ) し，この粒子を 189 個連ねた分子量 12,852 の シス-1,4-ポリイソプレン 10 本を用い，J-OCTAv1.3 ${ }^{13)} に て$ 作成した。この作成では，力場パラメータを DREDING ${ }^{14)}$ にて，粗視化ポテンシャルを簡易法 ${ }^{14)}$ にて計算した。ま た，2.2.2〜2.2.4の解析では，特に断らない限り，境界条 件は周期境界，アルゴリズムはNVT-NOSE-HOOVER ${ }^{14)}$, 温度は $27{ }^{\circ} \mathrm{C}$, 圧力は $0.1 \mathrm{MPa}$, 圧縮・伸長速度は $100 \mathrm{~m}$ /s，ポアソン比は 0.49 を基準条件とした。

\section{2 .2 ポリマー初期座標の発生}

アルゴリズムを基準条件から NPT-Berendsen(定圧法) ${ }^{14}$ に変えて，ポリマー初期座標を発生させた。解析セルは計 算の結果， $54.7 \times 54.7 \times 54.7 \AA$ となった.

\subsection{3 加硫過程シミュレーション}

加圧 (Press) 過程は, 試験用金型を用いた加硫過程を模 した．即ち，Y方向幅を固定し，Z方向を $10 \%$ 圧縮する事 により，X方向にゴムが流れ出す条件を設定した。温度・ 圧力保持 (Hold) 過程は, 温度を $150{ }^{\circ} \mathrm{C}$ に変え, 静的に 1,220 ps 緩和させた。抜圧放冷 (Release) 過程は，アルゴ リズムをNPT-BROWN CLARKE (定圧法) ${ }^{14)}$ に変え，常 温で静的に $11,760 \mathrm{ps}$ 緩和させた。

\section{2 .4 応力ーひずみ曲線}

2.2.3で得られた解析セルを X及び $\mathrm{Y}$ 方向に各一軸伸長 し, 各応力ーひずみ曲線を得た。応力は真值を用いた。 $\tan \delta$ は振幅 $\pm 5 \%, 1.02 \times 10^{11} \mathrm{~Hz}$ の振動条件で計算し, 応力とひずみの位相差より求めた。

\section{3. 結 果と考 察}

\section{1 走査型プローブ顕微鏡(SPM) 観測結果}

Figure 2 に試験用金型より得た加硫シート表面のSPM 観測結果を示した。図の白灰色の背景はN Rで，黒灰色は SBR，黒色部はカーボンブラックである。また，図周辺の 矢印は, ゴムのロール出し方向 (Mill Flow) と加硫での流 れ出し方向 (Mold Flow)を示した. 図中，(A) はロール出 し方向が垂直で流れ出し方向が水平方向の，(B) はロール 出し及び流れ出し方向が，ともに水平方向の加硫シートよ り得られた画像である. Figure 2 より SBR とカーボンブ ラックは，ともにロール出し方向ではなく，加硫での流れ 出し方向(図では水平方向)に並んでいる結果が得られた.

\subsection{TRの加硫異方性}

Table 1 は試験用金型を用いて得られた加硫ゴムのTRに 及ぼすロール列理と加硫時のゴム流れによる列理 (加硫列 理)の影響を示した. Table 1のNo.欄はFigure 2 の試験片 


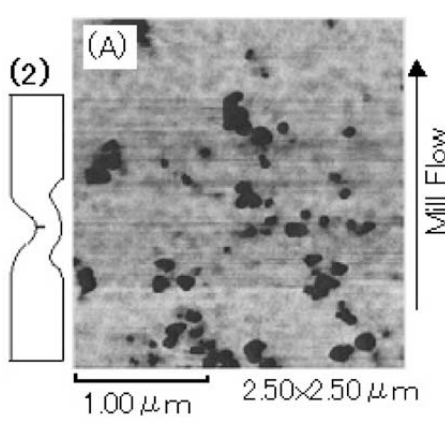

(1)

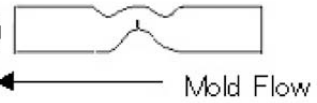

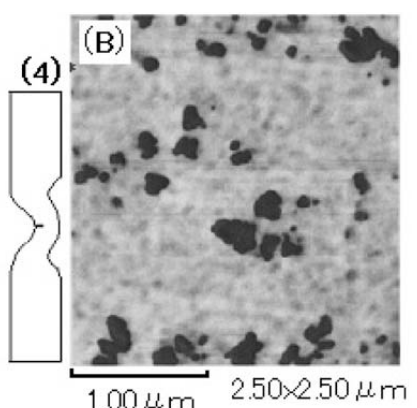

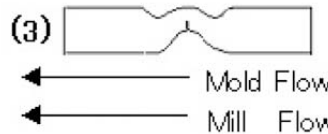

Figure 2 SPM images of test sheet surfaces of compound A cured by Test-Mold.

No. in parenthesis: same as the No. in Table 1.

方向 (1)〜 (4)に対応する. Test 1 のA配合において，(1) と (3)，または (2) と (4)の比較がロール出し方向の影響を 示し，(1)と（4)，または (2) と（3）の比較が加硫時の流れ出 し方向の 影響を示す．NRの多いA 配合ではロール列理の $T R$ への影響が小さく，加硫列理の影響が支配的に大きい 結果となった。ちなみにGurney ら ${ }^{3)}$ も同様な実験結果を 報告している，以後の実験では，Table 1の試験片採取方 向(1)及び(2)をそれぞれ，加硫時のゴムの流れ出し方向及 び直角方向とした。

Table 1のA 配合 (NR/SBR：83/17)において，TRは加 硫時の流れ出し方向が直角方向の約 $80 \%$ に減少しており， 加硫異方性が確認できた。更に，Table 2 のB配合 (NR/SBR : 100/0)の Test 2 の試験用金型加硫でも，Table 1 と同様に $T R$ は流れ出し方向が直角方向の $83 \%$ に減少し, 加硫異方性が確認できた。一方，Table 1 のC配合 （NR/SBR：0/100）は，TRの方向差に有意差無し（t検定） の結果が得られた，従って，この加硫異方性は，少なくと も NR含有率の高い配合に扔いて顕著 ${ }^{9)}$ であり，SBR

Table 1 Anisotropies of tear strength of compounds A and C cured by Test-Mold

\begin{tabular}{c|c|c|c|c|c}
\hline Comp'd & No. $^{* 1}$ & Mill Flow & Mold Flow & $T R / \mathrm{N} / \mathrm{mm}^{* 2}$ & $\mathrm{CV}^{* 3} / \%$ \\
\hline & $(1)$ & Across & Along & 88.7 & 3.3 \\
A & $(2)$ & Along & Across & 111.8 & 1.7 \\
\cline { 2 - 5 } (Test1) & $(3)$ & Along & Along & 89.7 & 5.0 \\
& $(4)$ & Across & Across & 113.3 & 4.3 \\
\hline \multirow{2}{*}{ C } & $(1)$ & Across & Along & 71.3 & 5.0 \\
\cline { 2 - 5 } (Test1) & $(2)$ & Along & Across & 75.5 & 8.0 \\
\hline
\end{tabular}

${ }^{* 1}$ No.s indicate the sampling directions cut off from the cured sheet, and are the same as those shown in Figure 2

*2 JIS K 6301

${ }^{* 3}$ Coefficient of variation $/ \%$

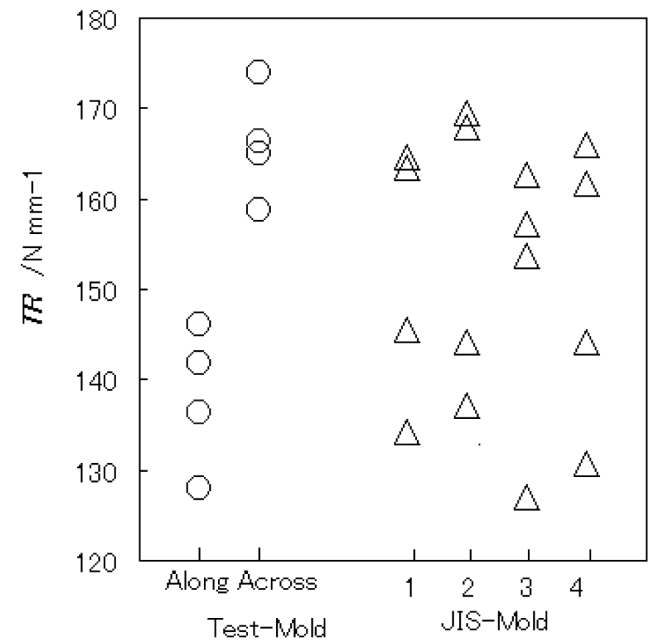

Figure 3 Comparison of tear strength scatterings of compound B cured by Test-Mold and those by JIS-Mold.

Tear strength values were obtained from Test 2 in Table 2 .

100\%のC配合では認められなかった。

Figure 3 は, Table 2 の Test 2 に示したTRの個々の值 を示したものである. Figure 3 の左側 2 列には, Table 2 の Test 2 の試験用金型加硫の流れ出し及び直角方向の

Table 2 Anisotropies of tear strength, tensile properties and cured sheet shrinkage of compound B cured by Test-Mold

\begin{tabular}{|c|c|c|c|c|c|c|c|c|c|}
\hline \multirow{2}{*}{ Test No. } & \multirow{2}{*}{ Mold } & \multirow{2}{*}{$\begin{array}{l}\text { Mold } \\
\text { Flow }\end{array}$} & & \multirow{2}{*}{$\begin{array}{c}T R \\
/ \mathrm{N} / \mathrm{mm}\end{array}$} & \multirow{2}{*}{$\begin{array}{c}M_{300} \\
/ \mathrm{MPa}\end{array}$} & \multirow{2}{*}{$\begin{array}{c}T_{\mathrm{B}} \\
/ \mathrm{MPa}\end{array}$} & \multirow{2}{*}{$\begin{array}{l}E_{\mathrm{B}} \\
/ \%\end{array}$} & \multicolumn{2}{|c|}{ Shrinkage /\% } \\
\hline & & & & & & & & observed & OCTA cell \\
\hline \multirow{6}{*}{ Test2 } & \multirow{4}{*}{ Test } & \multirow{2}{*}{ Along } & Average & $138(83)$ & $11.6(87)$ & $31.3(92)$ & $604(99)$ & 2.3 & $3.2 * 2$ \\
\hline & & & $\mathrm{CV} * 1 / \%$ & 5.7 & 2.6 & 2 & 1.7 & 0.7 & \\
\hline & & \multirow{2}{*}{ Across } & Average & $166(100)$ & $13.2(100)$ & $34.2(100)$ & $609(100)$ & 1.8 & $0.4 * 2$ \\
\hline & & & $\mathrm{CV}^{* 1 /} \%$ & 3.8 & 2.1 & 4.1 & 2.3 & 2.3 & \\
\hline & \multirow{2}{*}{ JIS } & \multirow{2}{*}{-} & Average & $152 * 3$ & & & & & \\
\hline & & & $\mathrm{CV}^{* 1 / \%}$ & $10.4^{* 4}$ & & & & & \\
\hline \multirow{4}{*}{ Test3 } & \multirow{2}{*}{ Test } & \multirow{2}{*}{ Along } & Average & 85.2 & 11.3 & 26.7 & 555 & & \\
\hline & & & $\mathrm{CV}^{* 1} / \%$ & 7.4 & 1.9 & 2.1 & 1.8 & & \\
\hline & \multirow{2}{*}{ JIS } & \multirow{2}{*}{-} & Average & 110.7 & 12.7 & 26.7 & 535 & & \\
\hline & & & $\mathrm{CV}^{* 1 / \%}$ & 13.6 & 2.2 & 3.3 & 3.4 & & \\
\hline
\end{tabular}

${ }^{* 1}$ Coefficient of variation $/ \%$

*2 OCTA calculation

*3 Average of 4 cavities' averages $(152,155,150,151 / \mathrm{N} / \mathrm{m})$ cured by JIS-Mold.

${ }^{*}{ }^{4}$ Average of 4 cavities' $\mathrm{CV}^{* 1} \mathrm{~s}(9.7,10.7,10.6,10.8 / \%)$ cured by JIS-Mold. 
個々のTR值を示した。また，Table 2 のTest 2 の JIS 金型 ( 4 面取り) 加硫の $T R$ 欄には 4 つのキャビティの平均值を 示したが，この元データである個々の TR值を, Figure 3 の右側 4 列に各キャビティ毎に示した。JIS 金型加硫ゴム の $T R$ の分布の下限及び上限付近に, 試験用金型加硫ゴム の流れ出し及び直角方向の TRが分布する結果となった.

また，Table 2 に示す様に試験用金型加硫ゴムの流れ出 し及び直角方向の $T R$ の変動係数 (Coefficient of variation) は 5.7 及び $3.8 \%$ あるるのに対し，JIS 金型加硫の 4 つのキ ヤビティの変動係数は 9.7 10.8\% (平均 10.4\%) であった. すなわち，試験用金型加硫ゴムのばらつきが，変動係数で JIS 金型加硫ゴムの 60\%以下に低減した，更に，金型比較 の追加試験の Table 2 の Test 3 でも，TRのばらつきは変 動係数で60\%以下に低減した。

\section{3 引張特性の加硫異方性}

試験用金型加硫ゴムの引張特性を Table 2 の Test 2 に示 した。 $T R$ と同様に $300 \%$ モ゙ュュラス $\left(M_{300}\right)$ 及び $T_{\mathrm{B}}$ は，加硫 時の流れ出し方向が直角方向の $90 \%$ 前後となり, 明らかに 異方性を示す結果となった。但し，伸び $\left(E_{\mathrm{B}}\right)$ は有意差が なかった。また，JIS 金型加硫ゴムと比較したTable 2 の Test 3 で， $M_{300}$ は試験用金型加硫ゴムがJIS 金型加硫ゴム より小さい結果となり，異方性を示したが， $T_{\mathrm{B}}$ 及び $E_{\mathrm{B}}$ で は有意差の無い結果となった。

\section{4 加硫列理観測結果}

試験用金型加硫シートの2.1.4による加硫列理観測では, Figure 4(A) (写真は 2 面取り金型の左キャビティで加硫 したシート)に見られるように，加硫列理が一定方向の弱 い引裂きパターンを示し，加硫時のゴムの流れ出しに対し て直角方向を示す結果が得られた。一方，JIS 金型加硫ゴ ムは，4面取りの外周に向かってゴムが流れ出すため， Figure 4(B) (写真は 4 面取り金型の左上キャビティで加 硫したシート)となり，弱い列理パターンが外周に沿う円 弧状となった，従って，加硫シート内の場所により列理が
異なり，Figure 3 の JIS 金型加硫ゴムに見られる $T R$ の大 きなばらつきと相関する結果となった.

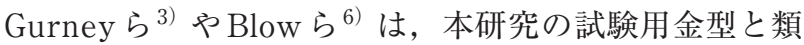
似の金型を用いた研究で，加硫列理の再現性に問題がある 事を報告している。本研究の試験用金型は，これらの 2 報 告の金型と異なり，加圧時にも空隙があるため，より安定 した加硫列理が発現できる1）ものと思われる.

\section{5 ミクロ試験の加硫異方性}

Table 3 に, 試験用金型加硫ゴムのミクロ引裂強さ，ミ クロ引張特性，架橋密度及び粘弾性を示した。

ミクロ引裂強さとミクロ引張特性はバルク (JIS 試験) の 物性 (Table 2) と類似の結果となった。また，加硫シート の内部(表面から $0.6 〜 1.3 \mathrm{~mm}$ ) は，表層部より大きな異方 性を示した。これは，金型との摩擦によって，表層部のゴ ム流れが，内部のゴム流れよりも小さくなったためと考え られる。この結果はゴム流れの大きさが $T R$, 引張特性や 粘弾性等の異方性の大きさに影響する事を示している.
(A)

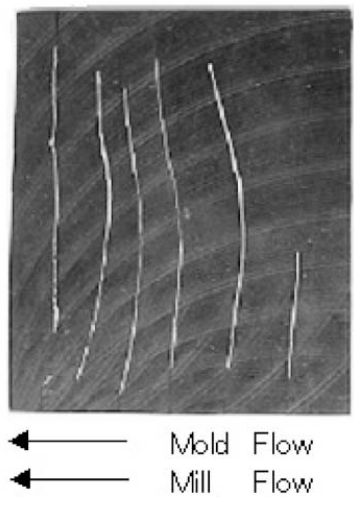

(B)

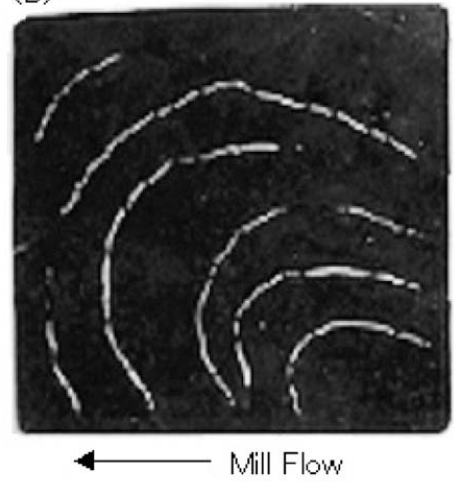

Figure 4 Photographs of easy tear trace in swollen cured sheets of compound $\mathrm{A}$.

(A) : Test sheet cured in the left cavity of Test-Mold (2-cavity mold).

(B) : Test sheet cured in the upper left cavity of JIS-Mold (4-cavity mold) .

Table 3 Anisotropies of tear strength and tensile strength properties of the microspecimen as well as crosslink-chain density and viscoelasticities of compound A cured by Test-Mold

\begin{tabular}{|c|c|c|c|c|c|c|}
\hline \multirow{2}{*}{$\begin{array}{l}\text { Cured } \\
\text { Sheet }\end{array}$} & \multirow{2}{*}{$\begin{array}{l}\text { Mold } \\
\text { Flow }\end{array}$} & Micro-TR & \multicolumn{3}{|c|}{ Micro-Tesile Properties } & \multirow{2}{*}{$\begin{array}{c}\text { Crosslink- } \\
\text { chain Density } \\
/ \mathrm{mol} / \mathrm{m}^{3}\end{array}$} \\
\hline & & $\begin{array}{l}\text { Micro-TR } \\
/ \mathrm{N} / \mathrm{mm}\end{array}$ & $\begin{array}{l}M_{300} \\
/ \mathrm{MPa}\end{array}$ & $\begin{array}{c}T_{\mathrm{B}} \\
/ \mathrm{MPa}\end{array}$ & $\begin{array}{l}E_{\mathrm{B}} \\
/ \%\end{array}$ & \\
\hline \multirow{2}{*}{ Innner $* 1$} & Along & $11.1(77)$ & $9.0(91)$ & $22.9(89)$ & $518(92)$ & $1.19(77)$ \\
\hline & Across & $14.3(100)$ & $9.9(100)$ & $25.7(100)$ & $557(100)$ & $1.55(100)$ \\
\hline \multirow{2}{*}{ Surface } & Along & $11.9(87)$ & $9.6(96)$ & $24.3(94)$ & $554(100)$ & $1.43(105)$ \\
\hline & Across & $13.6(100)$ & $9.8(100)$ & $25.9(100)$ & $553(100)$ & $1.37(100)$ \\
\hline \multirow{2}{*}{$\begin{array}{l}\text { Cured } \\
\text { Sheet }\end{array}$} & \multirow{2}{*}{$\begin{array}{l}\text { Mold } \\
\text { Flow }\end{array}$} & \multicolumn{3}{|c|}{ Viscoelasticity $1.25 \pm 0.3 \%$} & \multicolumn{2}{|c|}{ Viscoelasticity $15.0 \pm 0.5 \%$} \\
\hline & & $\begin{array}{c}\mathrm{E}^{\prime} \\
\mathrm{MPa}\end{array}$ & $\tan \delta$ & $\begin{array}{l}\text { Week Bond } \\
\times \mathrm{kT} / \mathrm{MPa}\end{array}$ & $\begin{array}{c}\mathrm{E}^{\prime} \\
/ \mathrm{MPa}\end{array}$ & $\tan \delta$ \\
\hline \multirow{2}{*}{ Innner $* 1$} & Along & $20.9(95)$ & $0.193(90)$ & $12.4(85)$ & $13.4(101)$ & $0.205(96)$ \\
\hline & Across & $21.9(100)$ & $0.216(100)$ & $14.6(100)$ & $13.3(100)$ & $0.213(100)$ \\
\hline
\end{tabular}

${ }^{* 1}$ Layer in $0.6 \sim 1.3 \mathrm{~mm}$ depth from the surface of test sheet 
Figure 5 に粘弾性の振幅依存性を示した。粘弾性測定の 初期ひずみ $1.25 \%$ では， $E^{\prime}$ 及び $\tan \delta$ は加硫時の流れ出し方 向が直角方向より低い值となり，異方性を示した。一方， 初期ひずみ $15 \%$ の $E^{\prime}$ と，この高振幅側の $\tan \delta$ では方向の 差がなかった. $\tan \delta$ と破断特性は相関する ${ }^{15)}$ と考えられ るため，類似の異方性を示す結果は妥当と考える.

また，初期ひずみ $1.25 \%$ では振幅増による $E^{\prime} の$ 低下 (Payne's effect) も異方性を示した。この振幅依存性より 計算したポリマーと充てん剂間等の弱い物理結合 (Week Bond ${ }^{16)}$ は, Table 3 の様に流れ出し方向が直角方向より 少なく，異方性を示した。

以上に示されたモジュラスや粘弾性挙動の検討のため, 非架橋，非充てんモデルのOCTAによる解析を試みた。

\section{6 高分子解析ソフト OCTA-Cognac ${ }^{8)}$ 解析結果}

Figure 6 に2.2.3の加硫過程シミュレーションの各過程 での応力を示した．加圧 (Press) 過程では Z 方向の圧縮に より，X方向に引張りの応力が発生した。圧力保持 (Hold) 過程では，Z及びX方向とも応力が低下し，一定值に収れ んした。抜圧放冷 (Release) 過程では，各応力がほぼ 0 $\mathrm{MPa}$ まで緩和した。実験デー夕は無いが，本計算結果は 妥当なものと思われる。また，この放冷過程(自由収縮)で の解析セルの収縮 (shrinkage)をTable 2 に併記した。 Table 2 に示す様に収縮はX (Along) 方向がY (Across) 方 向より大きく，実測值 (Table 2) と傾向が一致した.

次に，2.2.4より求めたX及び $\mathrm{Y}$ 方向への一軸伸長時の, 応力及び $\tan \delta$ のひずみ依存性を Figure 7 に示した。 また， Table 4 に応力ょり計算したモジュラスを示した。伸長 $20 \%$ 以下では，モジュラスと $\tan \delta$ はX方向がY方向より 小さく，実測 (Table 3) と類似の結果が得られた。但し， 伸長 30\%以上のモジュラスは，逆にX方向が $\mathrm{Y}$ 方向より大 きく，実測と異なる結果となった。一方， $\tan \delta$ はひずみ の増大とともに，XとY方向が同等となり，実測と類似の 結果が得られた.

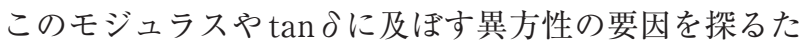
め, 伸長時のエネルギー変化を検討した. 本解析において, 全エネルギー $\left(U_{\text {total }}\right)$, ポテンシャルエネルギー $\left(U_{\text {pot }}\right)$ 及び 運動エネルギー $\left(U_{\mathrm{kin}}\right)$ は式 $(1)$ 及び $(2)$ で示される ${ }^{14)}$.

$$
\begin{aligned}
& U_{\text {total }}=U_{\text {pot }}+U_{\text {kin }} \\
& U_{\text {pot }}=U_{\text {bond }}+U_{\text {angle }}+U_{\text {torsion }}+U_{\text {nonbond }}
\end{aligned}
$$

ここで， $U_{\text {bond }}$ は結合伸縮ポテンシャル， $U_{\text {angle }}$ は結合変角 ポテンシャル， $U_{\text {torsion }}$ は結合二面角ポテンシャル， $U_{\text {non- }}$ bond は非結合相互作用ポテンシャルである.

Table 4 に示す様に，全エネルギー(Total Energy)の変 化はモジュラスと同様なひずみ依存性 (異方性)を示した.

さらに，各エネルギーの中で影響の最も大きな結合伸縮 (Bond) ポテンシャルエネルギーに注目し，このエネルギ 一変化を検討した。結合伸縮ポテンシャルエネルギー,
$U_{\text {bond }}$ は式(3)で計算される ${ }^{14)}$.

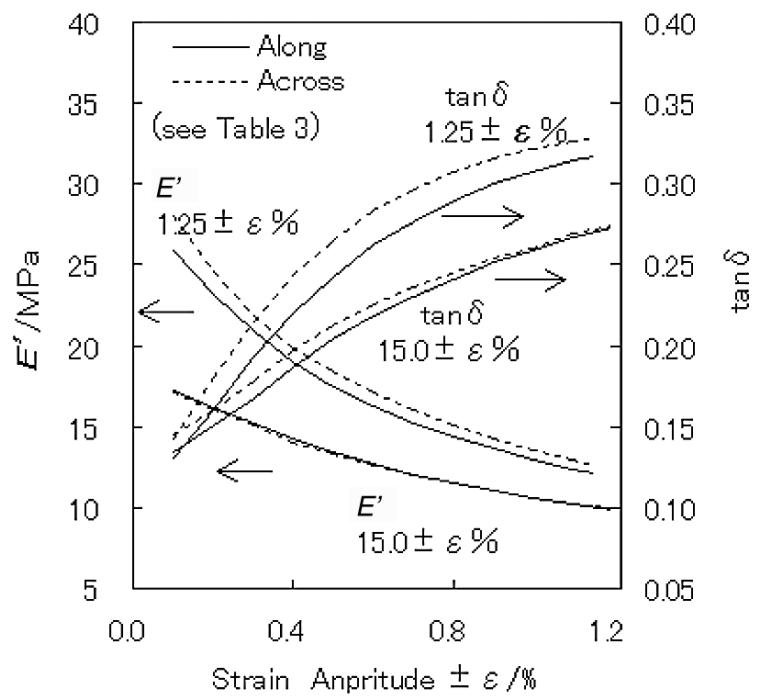

Figure 5 Strain dependence of $E^{\prime}$ and $\tan \delta$ of compound A cured by Test-Mold.

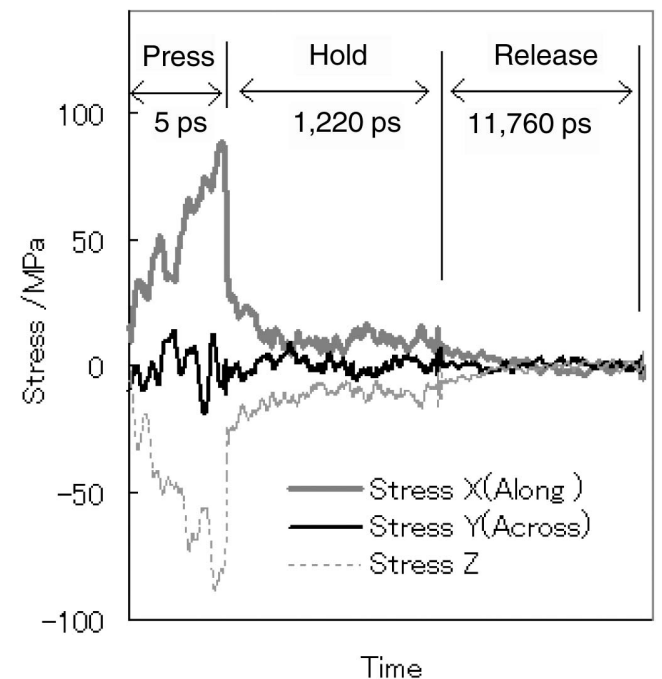

Figure 6 Stress changes of OCTA model in the cure stage by OCTA calculation.

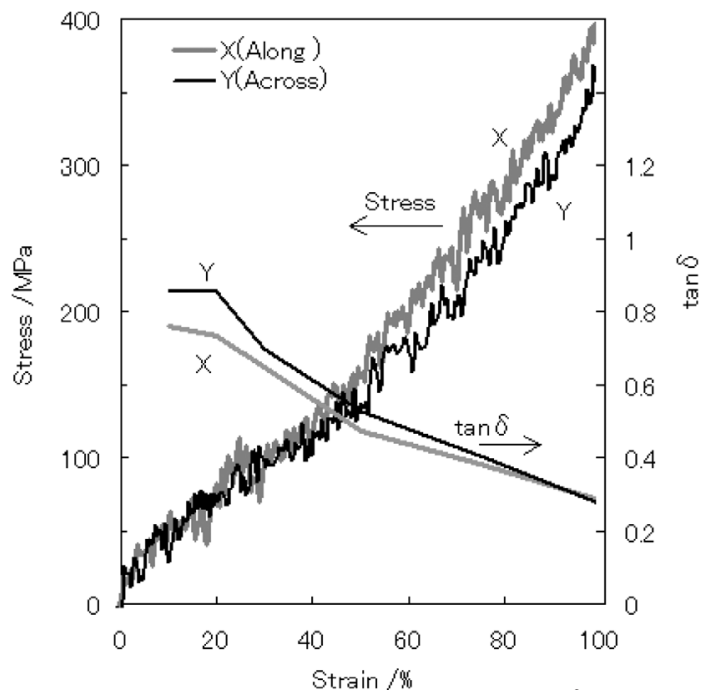

Figure 7 Strain dependence of stress and $\tan \delta$ of the OCTA Model by OCTA calculation. 
Table 4 Strain dependence calculations of modulus, energy changes and number of bonds ${ }^{* 1}$ of the OCTA Model

\begin{tabular}{|c|c|c|c|c|c|c|c|c|c|}
\hline \multirow{3}{*}{$\begin{array}{l}\text { Elong- } \\
\text { ation }\end{array}$} & \multirow{3}{*}{$\begin{array}{l}\text { Elongation } \\
\text { Direction }\end{array}$} & \multirow{3}{*}{$\begin{array}{l}\text { Modulus } \\
\text { /MPa }\end{array}$} & \multicolumn{6}{|c|}{ Energy Change $/ \mathrm{kJ} / \mathrm{mol}$ from $0 \%$ Elongation } & \multirow{3}{*}{$\begin{array}{c}\text { Numbers } \\
\text { of Bonds*1 } \\
\left(\mathrm{BR}^{* 1}>1.25\right)\end{array}$} \\
\hline & & & \multicolumn{4}{|c|}{ Potential Energy } & \multirow{2}{*}{$\begin{array}{l}\text { Kinetic } \\
\text { Energy }\end{array}$} & \multirow{2}{*}{$\begin{array}{l}\text { Total } \\
\text { Energy }\end{array}$} & \\
\hline & & & Bond & Angle & Torsion & Nonbond & & & \\
\hline \multirow{2}{*}{$10 \%$} & $\mathrm{X}$ (Along) & 52 & 35 & 51 & -10 & 70 & 0 & 147 & 23.8 \\
\hline & $\mathrm{Y}$ (Across) & 57 & 110 & 85 & -30 & 58 & 0 & 222 & 30.0 \\
\hline \multirow{2}{*}{$20 \%$} & $\mathrm{X}$ (Along) & 77 & 242 & 226 & -26 & 143 & 0 & 584 & 33.6 \\
\hline & $\mathrm{Y}$ (Across) & 82 & 251 & 211 & 0 & 110 & 0 & 572 & 32.5 \\
\hline \multirow{2}{*}{$30 \%$} & $\mathrm{X}$ (Along) & 98 & 424 & 354 & -35 & 162 & 0 & 906 & 45.5 \\
\hline & $\mathrm{Y}$ (Across) & 99 & 364 & 273 & 17 & 173 & 0 & 829 & 43.6 \\
\hline \multirow{2}{*}{$50 \%$} & $\mathrm{X}$ (Along) & 162 & 1,144 & 544 & -79 & 187 & 0 & 1,796 & 88.6 \\
\hline & $\mathrm{Y}$ (Across) & 148 & 954 & 458 & 1 & 220 & 0 & 1,633 & 81.2 \\
\hline \multirow{2}{*}{$100 \%$} & $\mathrm{X}$ (Along) & 402 & 5,311 & 1,883 & -156 & 319 & 0 & 7,358 & 306 \\
\hline & $\mathrm{Y}$ (Across) & 369 & 4,343 & 1,602 & -64 & 251 & 0 & 6,132 & 279 \\
\hline
\end{tabular}

${ }^{* 1}$ Number of bonds for which bond length ratio(BR=bond length/equilibrium bond length) is larger than 1.25 at the given elongation

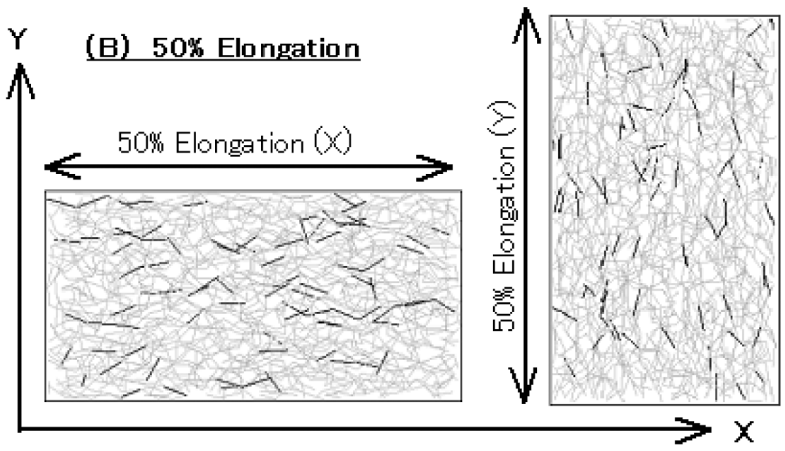

\section{Y (A) 10\% Elongation}

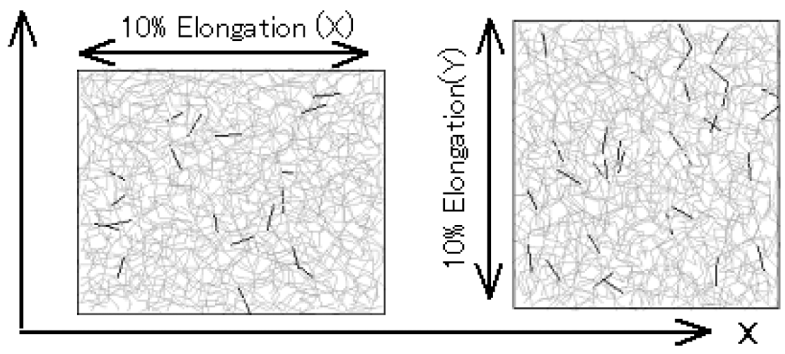

Figure 8 Highly stretched bonds of the OCTA Model by OCTA calculation.

Bond length ratio : Gray : $<1.25$; Black: $\geqq 1.25$.

Left side figures : The cells elongated to $\mathrm{X}$ direction.

Right side figures : The cells elongated to Y direction.

$U_{\text {bond }}(r)=(1 / 2) k\left(r-r_{0}\right)^{2}$

ここで, $k$ は弾性定数, $r$ は結合長さ， $r_{0}$ は平衡結合長さ である。

平衡結合長さに対する結合長さの比 $r / r_{0}$ を結合長比と定 義し, Figure 8 に10\%と $50 \%$ 伸長時の結合長比 1.25 未満と 以上の結合の分布状態を示した. Figure 8(A)の 10\%伸長 では, 結合長比 1.25 以上の結合が不均一に存在し，しかも， Table 4 にも示した様にX(Along) 方向がY (Across) 方向 より少ない結果が得られた。これは，2.2.3の抜圧放冷過程 におけるX方向の収縮によって，X方向の結合長さが緩和 されるためと考えられる，また，Figure 8(B)の50\%伸長
では，10\%伸長とは逆に，結合長比 1.25 以上の結合が，Y 方向よりも X方向の方が多い結果となった。この方向差 はTable 4 に示す様に，伸長 $20 \%$ 付近で逆転し，本計算の モジュラスと類似の伸長依存性を示した。本計算は非架橋 モデルのため，加硫初期のゴム流れによるポリマー配向の 影響が高伸長側で大きくなったと推定される．しかし，後 述の様に本実験の架橋ゴムでは, 絡み合いの解 (ほど) け等 の影響がポリマーの配向効果より大きい状態で架橋し，固 定すると推定される事より，高伸長側でのモジュラス等の 逆転は無いと思われる.

さらに，この結合長比の不均一性とその異方性をもたら す要因を検討したが，絡み合い等を含め，明確にはできな かった。

過去の研究において, 本研究の異方性と類似の現象につ いては, Kaang ら ${ }^{17)}$ やBarrès ら ${ }^{18)}$ の報告がある。すな わち, Kaang らは, 部分架橋した配合物を, 伸長状態で フル架橋するダブル架橋の研究で, フル架橋時の伸長率と モジュラスの関係を求めた。この伸長率が低い場合，モジ ユラスは伸長方向が直角方向より小さくなる結果を得て, 伸長による絡み合いの解(ほど)けの影響がポリマーの配向 効果より大きくなるためと考察している．また，Barrès らは，未加硫NR配合物にフリクションを掛けた場合に， この方向の粘度が低くなる結果を得た。この原因として, ネットワークの弱い構造の破壊を推定している.

本研究でも，ゴムの流れ出し方向に比較的低い伸長状態 で架橋されているため, KaangらやBarrèsらの伸長方向 の絡み合いの解(ほど)けや弱い構造の破壊の考察が当ては まると考えられる.

また, OCTA解析結果もこの考えを示唆するものであ る。 


\section{4. ま と め}

加硫時のゴムの流れ出しが一方向となる試験用金型を用 いて加硫したNR 配合物の実験では以下の結果が得られ た.

1 ) 引裂強さは加硫列理 (Mold Flow)の影響が支配的で あり，ロール列理 (Mill Flow)の影響は小さかった。

2) $T R, M_{300}, T_{\mathrm{B}}$ や粘弾性特性 $\left(E^{\prime}, \tan \delta\right)$ は, 加硫時 のゴムの流れ出し方向に伸長した場合が直角方向に伸 長した場合より小さい結果となった。

これらは一般的な破断特性や弾性率についての考え 方）とは逆の結果である。

3 ）加硫時のゴムの流れ出し方向が一定でない JIS 金型 加硫ゴムに比べ，試験用金型加硫ゴムの $T R$ は，ばら つきが小さく, 変動率で $60 \%$ 以下の結果となった.

4) OCTAによる粗視化分子動力学の解析では, 非架 橋，非充てんのNR モデルにもかかわらず，20\%以下 の伸長時のモジュラスや $\tan \delta$ は実験と同様な異方性 を示した。

KaangやBarrès らが考察した様に，本研究でも加硫初 期のゴム流れにより，流れ方向の絡み合いの解(ほど)けや 弱い構造の破壊が発生し，異方性の原因となったと考えら れる。

本研究に関し，助言をいただきました京都工芸䋐維大学 名誉教授, 山下晋三先生に感謝の意を表します。

\section{References}

1 ) Muramatsu, R.: Jpn. Kokai Tokkyo Koho 1993-278035 (1993)

2) For example, Nakayama, K.; Kaitou, A.: "Koubunsi wo naraberu", Koubunsi Gakkai Ed., Kyouritu Shuppan, Tokyo,
Chapter 3 (1993)

3 ) Gurney, W. A.; Gouth, V. E.: Rubber Chem. Technol., 20, 863 (1947)

4 ) Hamed, G. R.: J. Appl. Polym. Sci., 27, 4081 (1982)

5 ) Wheelans, M. A.: Rubber Chem. Technol., 51, 1023 (1978)

6 ) Blow, C. M.; Demirli, H. B.; Southwart, D. W.: J. Inst. Rubber Ind., 8, 244 (1974)

7 ) Chang, W. V.: Rubber Chem. Technol., 54, 449 (1981)

8 ) OCTA User's Group: "OCTA2006Rev1", http://octa.jp

9 ) Muramatsu, R.; Takezawa, H.: Nippon Gomu Kyokai Elastomer Touronkai Youshisyu, 17, C-2 (2004)

10) Muramatsu, R.; Takezawa, H.: Nippon Gomu Kyokai Elastomer Touronkai Youshisyu, 17, C-3 (2004)

11) TOYO TIRE \& RUBBER's Method: unpublished

12) Flory, P. J.; Rhener, J. Jr.: J. Chem. Phys., 11, 521 (1943)

13) JRI Solutions, Limited: "J-OCTA 1.3", http://www.jrisol.co.jp/nano

14) OCTA User's Group: "COARSE-GRAINED MOLECULAR DYNAMICS PROGRAM COGNAC USER'S MANUAL version 5.4", http://octa.jp, Chapters 2 and 5 (2003)

15) Andrews, E. H.: J. Mater. Sci., 9, 887 (1974)

16) "Koubunsikougakukouza 7 gomu no seisitsu to kakou", Koubunsi Gakkai Ed., Chijinsyokan, Tokyo, p.452 (1970); Tohara, H.: Proceedings of 4th Japan Congness on Testing Materials, p.132 (1961)

17) Kaang, S.; Gong, D.; Nah, C.: J. Appl. Polym. Sci., 65, 917 (1997)

18) Barrès, C.; Leblanc, J. L.; Guilet, S.: Polym. Test., 20, 329 (2001)

\section{日本語表記参考文献}

1) 村松凌：特開平 $5-278035$ (1993)

2 ）例えば，中山和郎，海藤彰：高分子をならべる，高分子学会編， 共立出版株式会社, 東京, 3 章 (1993)

9 ）村松凌，竹澤宏典：エラストマー討論会講演要旨集， 17, C-2 (2004)

10）村松凌，竹澤宏典：エラストマー討論会講演要旨集， $17, C-3$ (2004)

11）東洋ゴム工業法：未発表

16）高分子工学講座 7 ゴムの性質と加工, 高分子学会編, 地人書館, 東京, p.452 (1970) 